\title{
Ssciendo
}

DOI 10.2478/afepuc-2021-0004

(C) 2022 Author(s). This is an open access article licensed under the Creative Commons Attribution-NonCommercial-NoDerivatives 4.0 International

(https://creativecommons.org/licenses/by-nc-nd/4.0/)

\section{THE ANTHROPOMETRIC AND PHYSIOLOGICAL CHARACTERISTICS OF YOUNG ALGERIAN SOCCER PLAYERS}

\author{
Wahib Beboucha, Adel Belkadi, Abdelkader Benchehida, Ali Bengoua \\ Laboratory for Optimizing Research Programmes on Physical and Sports Activities, Institute of Physical \\ Education and Sport, University of Mostaganem (Algeria).
}

\begin{abstract}
Summary: Objective: The aim of this paper was to describe the anthropometric and physiological characteristics of young soccer players (U13) which were associated with their being successful or not as soccer players, and also to determine standard levels in the light of a test battery and indicators to select and guide the young talents as a scientific means to facilitate the selection. Method: A total of 390 soccer players age (U13). From 14 Algerian soccer clubs were enrolled and subjected to standard anthropometric, fitness (speed $20 \mathrm{~m}$, CMJ, skills-related performance testing. The testing battery will be described as will the process for converting test data into standardized scores. Data will be presented to show the strengths and weaknesses of some players. Result: After analysing the results based on the standard criteria for the proposed tests as well as the overall performance variable. And the ability of each youth to be selected according to their potential, and therefore it was stressed that the proposed criteria, which are scientific support for the field observation, should be emphasized to facilitate this process for Algerian soccer players. The findings from this study indicate that marked improvements and parameters associated with physical maturity such as height, weight, speed, VO2max, or chronological age are important to determine the success of a soccer player. At older ages, other factors such as agility seem to be more important. Nevertheless, players born in the 1st semester of the year are also more frequent in the older teams. These findings should be taken into account by trainers and coaches in order to avoid biasing their selection choices.
\end{abstract}

Keywords: standard levels, talents, battery test

\section{Introduction}

Soccer is recognized as the most widely practiced worldwide sport, 65 million players and 5 million referees and officials are actively involved in the game of Soccer (The FIFA 
2014) and efficient organization of the team is essential for optimal development of the abilities of every player (Gil et al. 2007), the control of the opponent, and the successful resolution of a match have received reasonable attention in the literature (Silva et al. 2010; Vescovi et al. 2011; Williams \& Reilly 2000). Therefore, players are placed in certain positions to fulfil specific tasks (Bate \& Jeffreys 2014; Drust, Reilly \& Williams 2009). Both the tactic and the position of players on the soccer field are essential for the organization of a soccer match (da Costa et al. 2009; Kannekens, Elferink-Gemser \& Visscher 2011). There is a growing body of literature that recognizes the importance of the growth, maturity status, functional capacities and skills of male youth soccer players (Malina et al. 2000, 2004, 2005; Malina 1994) with the aim of identification and selection of the best soccer player. Accordingly, many football clubs and national federations invest substantial resources into the detection, identification, and development of young talented soccer players, to ensure that the most promising players receive high-quality coaching and training conditions (Baker et al. 2017; Myers et al. 2014; Sarmento et al. 2018; Williams \& Reilly 2000).

The context of modern football is characterized by repeated evaluation of footballers' potential to succeed at the elite, adult level and for test selection (Baker et al. 2017; Schorer \& Elferink-Gemser 2013; Schorer et al. 2017; Söderström et al. 2018). Test selection begins with an assessment of sport-specific demands (physiological and biomechanical) (Cone 2012), followed by selection of tests and their associated validity and reliability (Cone 2012; Nabli et al. 2016; Wagner et al. 2019; Hoff 2005). Fitness testing may play an essential role in determining strength and conditioning before the athlete begins program and competitive season (baseline measurements)(Ferguson 2014; Walker \& Turner 2009).The physiological demands of soccer require athletes to be trained in several fitness components (Svensson \& Drust 2005), including aerobic capacity, aerobic power, speed, speed endurance, strength, power, and agility (da Silva, Guglielmo \& Bishop 2010; Sayers, Sayers \& Binkley 2008; Walker \& Turner 2009; Yilmaz 2014). Therefore, when evaluating and preparing athletes for competition, the importance of physical assessment via the implementation of appropriate, valid, and reliable fitness testing cannot be overlooked (Sayers, Sayers \& Binkley 2008). Fitness tests can be very effective for a number of reasons (Hoff 2005) including assessing an athlete's current level of fitness including the identification of an athlete's individual physical (Belkadi et al. 2019) strengths and weaknesses (Granacher et al. 2018; Hoff 2005; Sayers, Sayers \& Binkley 2008; Zemková \& Hamar 2018). Many physical tests have been implemented in clubs and academies over the years to evaluate physical performance in soccer players 
(Haugen \& Seiler 2015). This long list includes linear sprinting, agility, repeated sprint ability, VO2max, and Yo-Yo intermittent tests (Brocherie et al. 2015; Fernandez-Fernandez, Ulbricht \& Ferrauti 2014; Lockie, Risso, et al. 2018; Nabli et al. 2016; Wagner et al. 2019).

There are several reports that have provided recommendations for what assessments should be included in a testing battery for soccer players (Cone 2012; Walker \& Turner 2009; Sayers, Sayers \& Binkley 2008). The tests selected for soccer players should specifically assess those factors that relate to soccer match play (Mohamed et al. 2019). The battery presented was adopted for a U13 years men's soccer from 14 teams. Explanations as to why these assessments were used by this team's coaching staff are provided. And this will serve to highlight the validity of the adopted assessments which is essential for appropriate athlete data collection (Miller 2012; Hoffman 2011). Furthermore, this particular testing battery has been adopted within formerly published scientific research in accordance with Lockie et al. (Lockie, Moreno, et al. 2018) also detailed the reliability and validity of each assessment. The testing battery also followed recommendations outlined in several National Strength and Conditioning Association text books and published paper (Baker et al. 2017; Sarmento et al. 2018; Wagner et al. 2019; Fernandez-Fernandez, Ulbricht \& Ferrauti 2014; Miller 2012; Hoffman 2011; Bangsbo, Reilly \& Williams 2014). The purpose of this article is to provide physical trainers and coaches of football clubs with evidence-based information enabling the effective implementation of an appropriate battery of football-specific fitness tests for U13. Firstly, this article will deal with the rationale for fitness tests and will be specifically intended for tests outside the laboratory. Various field tests, which assess the various components of physical condition declared specific to football will then be described and evaluated. Finally, a rationale for the choice of recommended tests will be reasoned and a timeline for implementation will be outlined.

\section{Material \& methods}

\section{Participants}

The research was conducted on a sample of 390 soccer players belonging to the 14 top (U13) soccer club in Algeria which have at least 5 years of sport sand practice three training sessions per week (each about $90 \mathrm{~min}$ ) and competed regularly in regional and national tournaments. The number of players in each team and their average age are shown in Table1. The average age of the soccer players $(11.13 \pm 2.65)$. All participants and their parents were informed about the purpose as well as experimental risks and benefits of the research. Parents or legal guardians provided written informed consent before the investigation. All Soccer 
players were free from any injury that would prevent maximal effort during performance testing. The study was approved by the Ethics Committee of the University and conducted in accordance to the Declaration of Helsinki (World Medical Association 2013).

Table 1

Physical characteristics of the players in each competitive age group and results of comparisons between groups

\begin{tabular}{|c|c|c|c|c|c|c|c|}
\hline \multirow[b]{2}{*}{ Variable } & \multicolumn{2}{|c|}{$\begin{array}{c}\text { 11-12 years } \\
(n=186)\end{array}$} & \multicolumn{2}{|c|}{$\begin{array}{l}13 \text { years } \\
(n=204)\end{array}$} & \multirow[t]{2}{*}{$p$} & \multirow[t]{2}{*}{$F$} & \multirow[t]{2}{*}{$\eta^{2}$} \\
\hline & Mean & SD & Mean & $\mathrm{SD}$ & & & \\
\hline Chronological age (CA), years & 11,13 & 2,65 & 13,47 & 0,68 & $<0.01$ & 732,58 & 0,82 \\
\hline Skeletal age (SA), years & 12,29 & 1,56 & 13,98 & 1,28 & $<0.01$ & 163,14 & 0,51 \\
\hline SA minus CA, years & 0,16 & 0,91 & 0,51 & 0,60 & & 2,81 & 0,18 \\
\hline Weight, kg & 38,43 & 6,32 & 54,43 & 10,22 & $<0.01$ & 149,96 & 0,49 \\
\hline Height, cm & 144,93 & 6,82 & 163,83 & 9,42 & $<0.01$ & 217,95 & 0,58 \\
\hline Sitting height, cm & 73,33 & 3,22 & 82,03 & 5,02 & $<0.01$ & 189,14 & 0,55 \\
\hline Estimated leg length, cm & 72,03 & 4,62 & 82,13 & 5,32 & $<0.01$ & 173,79 & 0,53 \\
\hline Sitting heightratio,\% & 50,83 & 1,42 & 50,33 & 1,32 & $<0.01$ & 6,76 & 0,04 \\
\hline Sum of skinfolds, mm & 32,73 & 14,62 & 36,63 & 16,22 & $<0.01$ & 2,63 & 0,02 \\
\hline
\end{tabular}

\section{Study Protocol}

To guarantee an appropriate execution of the exploratory tests, two acquaintance preliminaries were led in two separate days during the week preceding testing. Following two days from the last tests, players achieved two testing sessions split by 72 hours. Before every meeting, members were approached to abstain from hard physical exercises within 48 hours preceding testing (Chamari et al. 2004). They were likewise required to wear similar attire and footwear. The assessment of linear sprinting, jumping, and agility are common to soccer (G. Hoare \& Warr 2000; Chamari et al. 2004) and were included in our battery of tests.

\section{Anthropometry, Somatotype and Body Composition}

In the first session, anthropometric characteristics including body height and mass were recorded. Each individual measurement and the sum of the 4 measurements were used for analysis. Fourskin folds (sub scapular, suprailiac, tricepsand medial calf). All the measurementswere made following the guidelines outlinedby the International Society for the Advancement of Kin- anthropometry (ISAK) by a level 2 ISAK anthropometrist.

\section{Estimation of Aerobic Capacity}

Aerobic abilities, agility and muscular power were tested. The yo-yo intermittent endurance test - level 1 (Krustrup et al. 2003; Bangsbo, Iaia \& Krustrup 2008; Cusano, Ascione $\&$ Mezzapesa 2019). The test consists of repeated $2 \times 20 \mathrm{~m}$ runs back and forth between the starting, turning, and finishing line at a progressively increased speed controlled by audio bleeps 
from a tape recorder (Bangsbo, Iaia \& Krustrup 2008). Between each running bout, the subjects have a $10 \mathrm{~s}$ active rest period consisting of $2 \times 5 \mathrm{~m}$ of jogging. When the subjects twice have failed to reach the finishing line in time, the distance covered is recorded and represents the test result.

\section{Estimation of the strength of the lower limbs}

Performed five maximal CMJs on a piezo-electric force platform Quattro Jump (Kistler, Switzerland) connected to a portable computer force data were recorded with a sample rate of $500 \mathrm{~Hz}$. This test involves the participant jumping, starting from an upright position, with arms free to move and was conducted following a protocol as in (Bosco 1992) recording the best of two jumps.

\section{Estimation of speed abilities}

The $20 \mathrm{~m}$ sprint is a well-known test considered suitable to discriminate the ability of soccer players to accelerate at a short distance as previously observed within the study (Moir et al. 2004). There is a $20 \mathrm{~m}$ track, in the stadium, with photocells positioned exactly $20 \mathrm{~m}$ from the starting line at height of $1 \mathrm{~m}$. The participants started from a standing position placing their forward foot $30 \mathrm{~cm}$ before the first photocell and were asked to sprint $20 \mathrm{~m}$. This test has demonstrated high levels of reliability: correlation coefficients of 0.91 between test and retest (Moir et al. 2004).

\section{Estimation of the agility}

A Illinois change of direction test (ICODT) was used to assess changes of direction (COD) profile among different patterns of movement including sprints, directional changes, turnings and slalom runs (Roozen 2004; Hachana et al. 2014). On command, from a standing position, participants ran from point A to point B as shown in Figure 1. They performed three trials resting $3 \mathrm{~min}$ in-between. Participants were also instructed not to cut over the cones but to move around without touching or hitting them. In case of failure, the trial was repeated after an extra recovery $(\sim 1 \mathrm{~min})$.

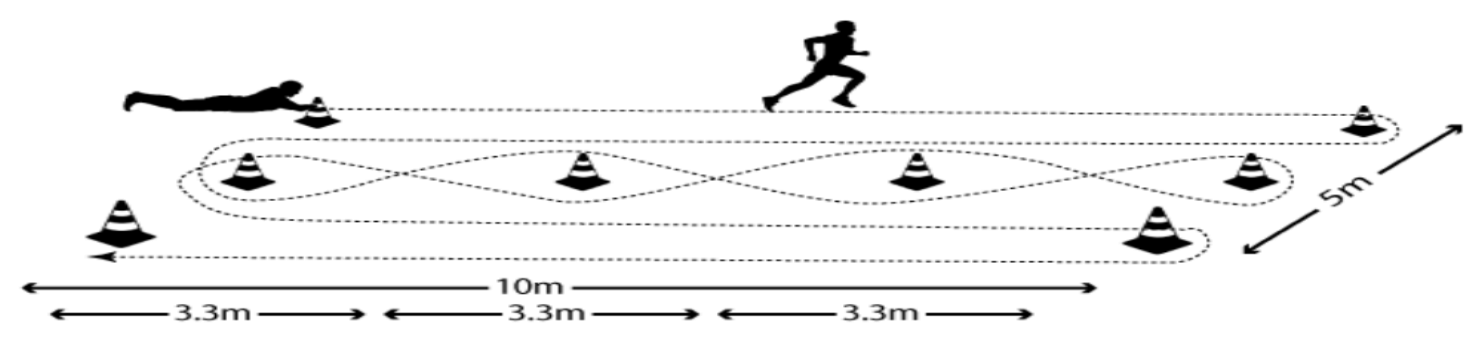

Figure 1 


\section{T-drill test with a ball}

The main reason for choosing the T-drill classic test as a basis for a novel test was to determine agility outcomes and soccer shooting skills (Stewart, Carroll \& Turner 2019; Šimonek 2019). The T-drill classic test is widely utilized to measure speed with directional changes such as forward sprinting, left- and right-side shuffling and back-pedaling. The Illinois agility test, which was also implemented in the current study, is commonly used to determine the ability to accelerate, decelerate, turn in different directions and run at different angles (Kutlu et al. 2012). Participants were instructed to sprint forward and kick the first ball with their right leg inside a soccer goal at $\sim 10 \mathrm{~m}$ distance. Then, they shuffled to the left side kicking the second ball and shuffled back to the right side kicking the third and the fourth ball by alternating the shooting leg. After that, they ran backwards to the starting position. For each ball kicked inside the goal (score) $0.25 \mathrm{~s}$ was subtracted from the total time required to complete the course. For example, in the event of four scores, a reduction of $1 \mathrm{~s}$ was applied to the total time. A recovery of 2 min was given between the trials.

\section{Skills tests}

The actual motor tasks of passing, controlling, dribbling and shooting the ball are fundamental aspects to the game of soccer (Ali 2011).

\section{Dribbling tests}

The ability to dribble the ball past opposing players is a hallmark of gifted players and hence is an oft-measured element of soccer skill (Kirkendall, Gruber \& Johnson 1987; G. Hoare $\&$ Warr 2000; Rosch et al. 2000; Chamari et al. 2004). Most of the tests draw upon traditional coaching techniques of dribbling around cones placed 2-4 $\mathrm{m}$ away from each other in a figureof-eight fashion (Sieghartsleitner et al. 2019) thus suggesting this type of test to be a valid and reliable indicator of soccer skill. Nevertheless, due to the nature of such tests they can be criticized for assessing the "technique" of dribbling rather than "skill" performance per/se.

\section{Shooting tests}

The clear aim of a soccer match is to score more goals than the opposing team. Therefore, one of the most highly valued and important skill elements within the game is the ability to score goals (Lyons, Al-Nakeeb \& Nevill 2006). Goal-shooting tests are usually part of a battery of skill tests designed to assess overall soccer game performance (Haaland \& Hoff 2003; Hachana et al. 2014). All of these tests require multiple attempts (using both feet) and aggregate points scored to determine overall performance. However, as shots are taken from a static position, it can be argued that they are assessing technique rather than skill. In addition, 
there was no information on the speed of the shot, thus players could have hit the ball at speeds slower than those typical of match play. Furthermore, some of the tests required participants to shoot from relatively short distances $(10 \mathrm{~m})$ from the goal so they may have resembled more of a pass than a shot.

\section{Passing tests}

Accurately passing the ball to a team mate is an essential ability required by soccer players and many researchers have devised tests to examine this aspect (Rosch et al. 2000; Gil et al. 2007; Figueiredo et al. 2009; Walker \& Turner 2009; Ali 2011). Studies were completed in this purpose (G. Hoare \& Warr 2000) instructing players to pass the ball over distances of 5 $\mathrm{m}$ for $15 \mathrm{~min}$; experienced coaches would then decide on performance ability.

\section{Wall-pass tests}

These tests require players to pass the ball through the air against a wall, control the rebound and make further air-borne passes against the wall typically with a set time limit and toward specific target a reason the wall (G. Hoare \& Warr 2000; Williams \& Reilly 2000; Silva et al. 2010; Turner et al. 2011; Hachana et al. 2014). Although a number of attributes are being assessed (including passing accuracy and control), this type of repeated wall-volley passing lacks ecological validity.

\section{Statistical analysis}

General characteristics of the participants were presented as means and standard deviations. Descriptive statistics were calculated by age group for all variables. Effect size was estimated with partial eta squared ( $\eta 2)($ Lakens 2013). Level of significance was accepted at $P$ $<0.05$.

\section{Results}

Table 2 provides an overview of the descriptive characteristics of the measured variables for U13 players. The analysis results show that all the applied variables are normally distributed (the data is not presented). Statistical differences between the groups in anthropometric measures and skill tests between players in different age are established in the variables: Fastest sprint $(F=63,86 ; p=.0 .01)$, Agility shuttle run $(F=102,41 ; p=.0 .01)$, Intermittent endurance run $(F=82,75 ; p=.0 .01)$, Squat jump $(F=57,94 ; p=.0 .01)$, Countermovement jump $(F=59,06 ; p=.0 .01)$, Ball control $(F=23,54 ; p=.0 .01)$, Dribbling speed $(F$ $=107,55 ; \mathrm{p}=.0 .01)$, Wall pass $(\mathrm{F}=39,51 ; \mathrm{p}=.0 .01)$, Shooting accuracy $(\mathrm{F}=12,1 ; \mathrm{p}=.0 .01)$. 
Table 2

Descriptive statistics for age and the skill tests for the total sample $(n=390)$ of adolescent soccer players

\begin{tabular}{|l|c|c|c|c|c|c|c|}
\hline & \multicolumn{1}{|c|}{$\mathbf{1 1 - 1 2}$ years $(\mathbf{n}=\mathbf{1 8 6})$} & $\mathbf{1 3}$ years $(\mathbf{n}=\mathbf{2 0 4})$ & & & \\
\hline Variable & Mean & SD & Mean & SD & F & p & n2 \\
\hline Fastest sprint, s & 8,37 & 0,5 & 7,8 & 0,39 & 63,86 & $<0.01$ & 0,29 \\
\hline Mean sprint, s & 8,79 & 0,6 & 8,06 & 0,43 & 76,22 & $<0.01$ & 0,33 \\
\hline Agility shuttle run, s & 20,55 & 1,32 & 18,69 & 0,92 & 102,41 & $<0.01$ & 0,4 \\
\hline Intermittent endurance run, m & 1371 & 731 & 2556 & 912 & 82,75 & $<0.01$ & 0,35 \\
\hline Squat jump, cm & 23,8 & 4,3 & 28,8 & 4 & 57,94 & $<0.01$ & 0,27 \\
\hline Counter-movement jump, cm & 26,2 & 4,5 & 31,9 & 4,9 & 59,06 & $<0.01$ & 0,27 \\
\hline Ball control, no. Hits & $23.9^{*}$ & 22,1 & $68.4^{*}$ & 82,3 & 23,54 & $<0.01$ & 0,13 \\
\hline Dribbling speed, s & 15,77 & 1,81 & 13,36 & 0,88 & 107,55 & $<0.01$ & 0,41 \\
\hline Wall pass, points & 18 & 3,2 & 21,2 & 3,2 & 39,51 & $<0.01$ & 0,2 \\
\hline Shooting accuracy, points & 6,5 & 2,5 & 8,1 & 3,1 & 12,1 & $<0.01$ & 0,07 \\
\hline
\end{tabular}

\section{Discussions}

The findings of the current study show that talent selection models with the single dimensions lead in general to significant predictions with the aim of an early differentiation between $11-12$ years and 13 years old players. Many talent identification models showed superiority over random predictions and were also calibrated appropriately for the U11, U12, and U13 age groups). Compared to the significance of predictions and the higher explained variance from the more extensive, multidimensional selection models within a similar group of participants, the less extensive models in the current study indicate substantially lower prognostic validity (Sieghartsleitner et al. 2019). This may underline the assumed advantages of multidimensionality over less extensive models (Vaeyens et al. 2008; Williams \& Reilly 2000; Zuber et al. 2016). However, as long as these multidimensional models are not easily applicable to talent selection in the field (Belkadi et al. 2015), the immediate comparison between possible predictors of later performance may be of certain relevance within talent research.

The findings from this study support the discriminant validity of tests as a talent identification tool for measuring skill proficiency. High-level players displayed proficient skill behaviours for soccer-specific actions related to passing and controlling the ball along with completing more total involvements. This study's methodological approach provides coaches with a simplistic way of assessing soccer-specific skills in a practical setting. Set teams allow for players to self-discover technical and tactical strategies for problem solving with their teammates to meet the constraints of the fitness tests and adapt these as the relationship with their teammates develops (Davids et al. 2013). As players in a talent identification setting often 
develop with the same teammates, it seems logical to use set teams within small-sided games. However, it is important for future research to also investigate the use of small-sided games for measuring skill proficiency when players compete in randomized teams. Randomizing teams will likely impose different technical and tactical constraints on players as they will have to adapt their behaviour according to the proficiency of their teammates. This approach may allow coaches to determine the cooperative nature of players with a diverse number of individuals.

As expected, anthropometric characteristics increased across the age groups as did the performance in functional capabilities. Previews study Deprez et al. (2014a) was evaluated in comparison with our study on the anthropometric and functional profile of 390 young soccer players between 11 and 13 years old in Algeria. An increase in anthropometric and function al measurements was observed as age increased. It has been verified that between the U11 and U12 categories, selection processes focus primarily on anthropometric characteristics of the goalkeepers and specific motor skills for midfield players. After the peak growth rate (U13), anaerobic performance becomes an important indicator (Saddek et al. 2020) to distinguish attackers from other positions.

Based on the immediate comparisons of different predictors of future performance in youth football, the current research contrasted the value of two different areas of motor performance for early talent selection. In doing so, there was a continuous superiority of sprint in descriptive values within each analysed age group through early (U11/U12) and middle adolescence (U13) despite the higher measurement reliability of the sprint test. None of the four comparisons at the different age groups led to a significant difference between sprint of U12 and $\mathrm{U} 13(.07 \leq \mathrm{N} 2 \leq .65)$.

Aerobic endurance assessed by the Yo-Yo Intermittent Recovery Test Level 1 was shown to be a predictor of defensive tactical performance in the U13 category, and explained $53 \%$ of the variance (Borges et al. 2018). The soccer defensive principles require constant movements of the player in the game space to regain ball possession. It is possible that the aerobic metabolism contributes significantly to supplying the energy demands of these movements where players with superior cardio- respiratory fitness are able to advance to the opponent's field to attack and/or return to cover and defend their zone more effectively (Santos and Soares 2001).

In the U13 category, training experience explained 19\% of the variance in defensive tactical performance. Figueiredo et al. (2011), analysing predictors of functional capabilities 
and specific motor skills in 390 young Algerian soccer players, concluded that training experience influenced shooting accuracy $(\mathrm{R} 2=0.07)$ and dribbling ability $(\mathrm{R} 2=0.41)$. Together these findings and the results of the present study demonstrate the importance of training experience in technical and tactical development in youth soccer.

Collectively, the Yo-Yo test, the Counter Movement Jump, abdominal strength, and body mass predicted $43 \%$ of the variance in defensive tactical performance of $11-13$ yearold soccer players. It is possible that the strongest players were encouraged by coaches to adopt more defensive roles and tactics, as greater body size and physical strength contribute to an advantage in the defensive system, since invasion sports are characterized by intense physical contact (Costa et al. 2010). Consistent with this finding, Deprez et al. (2014a) reported that U11 and U13 defenders were less tall and less heavy than midfielders and attackers, suggesting prevalence of taller, stronger players, more advanced in the maturational process.

As a practical application of these results, it is suggested that clubs and federations avoid selecting players guided by unilateral criteria favoring only physical and morphological advantages (Vandendriessche et al. 2012). Tactical, technical, and psychological qualities together with functional capabilities manifest themselves in symbiosis during the game and should be seen in that way during selection, detection, and sporting formation processes (Jones and Drust 2007).

A possible limitation of the study was the adoption of a cross-sectional design to the detriment of the longitudinal section which limits understanding of the variables during the maturational process. Future research should seek to employ more accurate measures of maturation. However, this study may contribute to future research involving the underlying processes in the development of young soccer players aiming to optimize this complex process identification.

\section{Conclusion}

This study was the first to examine the applicability of battery test as an assessment tool to determine the skill proficiency of youth soccer players. It was observed that players from the high-level academy displayed a significantly greater number of attempted and completed passes, touches, and overall skill involvements when compared with low-level players. In addition, skill proficiency remained relatively constant across different small-sided games (Bennett 2019). 
Collectively, these findings support the use of battery test as a skill assessment tool for talent identification purposes. The information gained from such assessments can assist coaches in determining the potential of youth soccer.

Funding: financing was granted by Algerian General Directorate for Scientific Research and Technological Development (DGRSDT-MESRS) during this study.

Conflicts of interest: the authors state no conflicts of interest regarding this study.

Acknowledgements: We thank the Algerian General Directorate for Scientific Research and Technological Development (DGRSDT-MESRS) for their co-operation and help in setting up the study. also, for maintaining and supporting finances and quality of research.

\section{References}

1. ALI, A., 2011. Measuring soccer skill performance: a review. Scandinavian Journal of Medicine \& Science in Sports. 21(2), pp. 170-183. ISSN 1600-0838. DOI 10.1111/j.16000838.2010.01256.x.

2. BAKER, J., S. COBLEY, J. SCHORER, N. WATTIE, S. COBLEY, J. SCHORER \& N. WATTIE, 2017. Routledge Handbook of Talent Identification and Development in Sport [en línea]. S.1.: Routledge. [Consulta: 23 enero 2020]. ISBN 978-1-315-66801-7. Disponible en: https://www.taylorfrancis.com/books/e/9781315668017.

3. BANGSBO, J., F. M. IAIA \& P. KRUSTRUP, 2008. The Yo-Yo intermittent recovery test. Sports medicine. 38(1), pp. 37-51.

4. BANGSBO, J., T. REILLY \& A. M. WILLIAMS, 2014. Science and Football III. S.1.: Routledge. ISBN 978-1-317-83294-2.

5. BATE, R.G. \& I. JEFFREYS, 2014. Soccer Speed. S.1.: Human Kinetics. ISBN 978-14925-8480-3.

6. BELKADI, A., A. BENCHEHIDA, O. BENBERNOU \& M. SEBBANE, 2019. Competencies and training needs and its impact on determining the professional skills of Algerian elite coaches. International Journal of Physical Education, Fitness and Sports. 8(3), pp. 51-61. ISSN 2457-0753. DOI 10.26524/ijpefs1936.

7. BELKADI, A., B. OTHMAN, S. M. MOHAMED, J. GLEYSE, B. ADEL, B. OTHMAN, S. MOHAMED, L. M. ABDELHAFID \& J. GLEYSE, 2015. Contribution to the Identification of the Professional Skills Profile of Coaches in the Algerian Sport Judo System. International Journal of Sports Science. 5(4), pp. 145-150. ISSN 2169-8791. 
8. BENNETT, K. J. M., 2019. An Australian perspective on talent identification and development in soccer. S.1.: s.n.

9. BORGES, P. H., S. CUMming, E. R. RONQUE, F. CARDOSO, A. AVELAR, L. RECHENCHOSKY, I. T. DA COSTA \& W. RINALDI, 2018. Relationship between tactical performance, somatic maturity and functional capabilities in young soccer players. Journal of human kinetics. 64(1), pp. 160-169.

10. BOSCO, C., 1992. L'évaluation de la force par le test de Bosco. S.l.: Società stampa sportiva.

11. BROCHERIE, F., O. GIRARD, R. FAISS \& G. P. MILLET, 2015. High-intensity intermittent training in hypoxia: a double-blinded, placebo-controlled field study in youth football players. The Journal of Strength \& Conditioning Research. 29(1), pp. 226-237.

12. CHAMARI, K., Y. HACHANA, Y. B. AHMED, O. GALY, F. SGHAIER, J. C. CHATARD, O. HUE \& U. WISLØFF, 2004. Field and laboratory testing in young elite soccer players. British journal of sports medicine. 38(2), pp. 191-196.

13. CONE, J. R., 2012. Soccer-Specific Performance Testing of Fitness and Athleticism: The Development of a Comprehensive Player Profile. Strength \& Conditioning Journal. 34(5), pp. 11-19. ISSN 1524-1602. DOI 10.1519/SSC.0b013e3182575e8c.

14. CUSANO, P., A. ASCIONE \& G. N. MEZZAPESA, 2019. Reliability of aerobic and anaerobic field tests in in measuring athletes' performances: A statistical approach on a cohort of 100 subjects. En: Accepted: 2018-10-29T10:14:04Z [en línea], [Consulta: 6 junio 2020]. ISSN 1988-5202. DOI 10.14198/jhse.2019.143.02. Disponible en: http://rua.ua.es/dspace/handle/10045/82692.

15. DA COSTA, I. T., J. M. G. DA SILVA, P. J. GRECO \& I. MESQUITA, 2009. Tactical principles of Soccer: concepts and application. Motriz. 15(3), pp. 657-668.

16. DA SILVA, J. F., L. G. A. GUGLIELMO \& D. BISHOP, 2010. Relationship Between Different Measures of Aerobic Fitness and Repeated-Sprint Ability in Elite Soccer Players. The Journal of Strength \& Conditioning Research. 24(8), pp. 2115-2121. ISSN 1064-8011. DOI 10.1519/JSC.0b013e3181e34794.

17. DRUST, B., T. REILLY \& A. M. WILLIAMS, 2009. International Research in Science and Soccer. S.1.: Routledge. ISBN 978-1-135-99955-1.

18. FERGUSON, B., 2014. ACSM's Guidelines for Exercise Testing and Prescription 9th Ed. 2014. The Journal of the Canadian Chiropractic Association. 58(3), pp. 328. ISSN 00083194. 
19. FERNANDEZ-FERNANDEZ, J., A. ULBRICHT \& A. FERRAUTI, 2014. Fitness testing of tennis players: How valuable is it? Br J Sports Med. 48(Suppl 1), pp. i22-i31.

20. FIGUEIREDO, A. J., C. E. GONÇALVES, M. J. COELHO E SILVA \& R. M. MALINA, 2009. Youth soccer players, 11-14 years: maturity, size, function, skill and goal orientation. Annals of Human Biology. 36(1), pp. 60-73. ISSN 1464-5033. DOI 10.1080/03014460802570584.

21. G. HOARE, D. \& C. R. WARR, 2000. Talent identification and women's soccer: an Australian experience. Journal of sports sciences. 18(9), pp. 751-758.

22. GIL, S. M., J. GIL, F. RUIZ, A. IRAZUSTA \& J. IRAZUSTA, 2007. Physiological and anthropometric characteristics of young soccer players according to their playing position: relevance for the selection process. Journal of Strength and Conditioning Research. 21(2), pp. 438-445. ISSN 1064-8011. DOI 10.1519/R-19995.1.

23. GRANACHER, U., C. PUTA, H., H. W. GABRIEL, D. G. BEHM \& A. ARAMPATZIS, 2018. Neuromuscular Training and Adaptations in Youth Athletes. S.1.: Frontiers Media SA. ISBN 978-2-88945-627-7.

24. HAALAND, E. \& J. HOFF, 2003. Non-dominant leg training improves the bilateral motor performance of soccer players. Scandinavian journal of medicine \& science in sports. 13(3), pp. 179-184.

25. HACHANA, Y., H. CHAABÈNE, G. B. RAJEB, R. KHLIFA, R. AOUADI, K. CHAMARI \& T. J. GABBETT, 2014. Validity and Reliability of New Agility Test among Elite and Subelite under 14-Soccer Players. PLOS ONE. 9(4), pp. e95773. ISSN 1932-6203. DOI 10.1371/journal.pone.0095773.

26. HAUGEN, T. \& S. SEILER, 2015. Physical and physiological testing of soccer players: why, what and how should we measure? Sportscience. 19, pp. 10-27.

27. HOFF, J., 2005. Training and testing physical capacities for elite soccer players. Journal of Sports Sciences. 23(6), pp. 573-582. ISSN 0264-0414. DOI 10.1080/02640410400021252.

28. HOFFMAN, J., 2011. NSCA's Guide to Program Design. S.1.: Human Kinetics. ISBN 14925-8277-8.

29. KANNEKENS, R., M. T. ELFERINK-GEMSER \& C. VISSCHER, 2011. Positioning and deciding: key factors for talent development in soccer. Scandinavian Journal of Medicine \& Science in Sports. 21(6), pp. 846-852. ISSN 1600-0838. DOI 10.1111/j.16000838.2010.01104.x. 
30. KIRKENDALL, D. R., J. J. GRUBER \& R. E. JOHNSON, 1987. Measurement and evaluation for physical educators. S.1.: s.n. ISBN 0-87322-081-1.

31. KRUSTRUP, P., M. MOHR, T. AMSTRUP, T. RYSGAARD, J. JOHANSEN, A. STEENSBERG, P. K. PEDERSEN \& J. BANGSBO, 2003. The Yo-Yo Intermittent Recovery Test: Physiological Response, Reliability, and Validity. Medicine \& Science in Sports \& Exercise. 35(4), pp. 697-705. ISSN 0195-9131. DOI 10.1249/01.MSS.0000058441.94520.32.

32. KUTLU, M., H. YAPICI, O. YONCALIK \& S. CELIK, 2012. Comparison of a new test for agility and skill in soccer with other agility tests. Journal of Human Kinetics. 33, pp. 143-150. ISSN 1640-5544. DOI 10.2478/v10078-012-0053-1.

33. LAKENS, D., 2013. Calculating and reporting effect sizes to facilitate cumulative science: a practical primer for t-tests and ANOVAs. Frontiers in Psychology [en línea], 4. [Consulta: 3 febrero 2021]. ISSN 1664-1078. DOI 10.3389/fpsyg.2013.00863. Disponible en: https://www.frontiersin.org/articles/10.3389/fpsyg.2013.00863/full.

34. LOCKIE, R. G., M. R. MORENO, A. LAZAR, A. J. ORJALO, D. V. GIULIANO, F. G. RISSO, D. L. DAVIS, J. B. CRELLING, J. R. LOCKWOOD \& F. JALILVAND, 2018. The physical and athletic performance characteristics of Division I collegiate female soccer players by position. The Journal of Strength \& Conditioning Research. 32(2), pp. 334-343.

35. LOCKIE, R. G., F. G. RISSO, D. V. GIULIANO, A. J. ORJALO \& F. JALILVAND, 2018. Practical Fitness Profiling Using Field Test Data for Female Elite-Level Collegiate Soccer Players: A Case Analysis of a Division I Team. Strength \& Conditioning Journal. 40(3), pp. 58. ISSN 1524-1602. DOI 10.1519/SSC.0000000000000343.

36. LYONS, M., Y. AL-NAKEEB \& A. NEVILL, 2006. Performance of soccer passing skills under moderate and high-intensity localized muscle fatigue. Journal of Strength and Conditioning Research. 20(1), pp. 197.

37. MALINA, R. M., 1994. Physical growth and maturation of young athletes. En: 389, Exerc Sport Sci Rev. 22, pp. 389-433. 14

38. MALINA, R. M., S. P. CUMMING, A. P. KONTOS, J. C. EISENMANN, B. RIBEIRO \& J. AROSO, 2005. Maturity-associated variation in sport-specific skills of youth soccer players aged 13-15 years. En: 515, J Sports Sci. 23, pp. 515-522. 18

39. MALINA, R. M., J. C. EISENMANN, S. P. CUMMING, B. RIBEIRO \& J. AROSO, 2004. Maturity-associated variation in the growth and functional capacities of youth football (soccer) players 13-15 years. En: 555, Eur J Appl Physiol. 91, pp. 555-562. 19 
40. MALINA, R. M., M. E. PENA REYES, J. C. EISENMANN, L. HORTA, J. RODRIGUES \& R. MILLER, 2000. Height, mass and skeletal maturity of elite Portuguese soccer players aged 11-16 years. En: 685, J Sports Sci. 18, pp. 685-693. 20

41. MILLER, T. A., 2012. NSCA's Guide to Tests and Assessments. S.1.: Human Kinetics. ISBN 1-4925-8278-6.

42. MOHAMED, K. S., K. MOHAMED, S. MOHAMMED, D. MOKRANI \& A. BELKADI, 2019. The Effect of Heavy Weight Training on Physiological Abilities of Soccer Players Under the Age 21 Years Old. Acta Facultatis Educationis Physicae Universitatis Comenianae. 59(1), pp. 33-43. DOI 10.2478/afepuc-2019-0004.

43. MOIR, G., C. BUTTON, M. GLAISTER \& M. H. STONE, 2004. Influence of familiarization on the reliability of vertical jump and acceleration sprinting performance in physically active men. Journal of strength and conditioning research. 18(2), pp. 276-280.

44. MYERS, B. A., W. L. JENKINS, C. KILLIAN \& P. RUNDQUIST, 2014. NORMATIVE DATA FOR HOP TESTS IN HIGH SCHOOL AND COLLEGIATE BASKETBALL AND SOCCER PLAYERS. International Journal of Sports Physical Therapy. 9(5), pp. 596-603. ISSN 2159-2896.

45. NABLI, M. A., N. B. ABDELKRIM, I. JABRI, T. BATIKH, C. CASTAGNA \& K. CHAMARI, 2016. Fitness Field Tests' Correlation With Game Performance in U-19Category Basketball Referees. International journal of sports physiology and performance. 11(8), pp. 1005-1011.

46. ROOZEN, M., 2004. Illinois agility test. NSCA's Performance Training Journal. 3(5), pp. $5-6$.

47. ROSCH, D., R. HODGSON, L. PETERSON, T. GRAF-BAUMANN, A. JUNGE, J. CHOMIAK \& J. DVORAK, 2000. Assessment and evaluation of football performance. The American journal of sports medicine. 28(5_suppl), pp. 29-39.

48. SADDEK, B., J. B. J. COQUART, L. MOUROT, B. ADEL, M. M. IDRISS, B. ALI \& M. DJAMEL, 2020. Comparison of Two Tests to Determine the Maximal Aerobic Speed. Acta Facultatis Educationis Physicae Universitatis Comenianae. 60(2), pp. 241-251. DOI 10.2478/afepuc-2020-0020.

49. SARMENTO, H., M. T. ANGUERA, A. PEREIRA \& D. ARAÚJO, 2018. Talent Identification and Development in Male Football: A Systematic Review. Sports Medicine (Auckland, N.Z.). 48(4), pp. 907-931. ISSN 1179-2035. DOI 10.1007/s40279-017-0851-7. 
50. SAYERS, A., B. E. SAYERS \& H. BINKLEY, 2008. Preseason Fitness Testing in National Collegiate Athletic Association Soccer. Strength \& Conditioning Journal. 30(2), pp. 70-75. ISSN 1524-1602. DOI 10.1519/SSC.0b013e31816a8849.

51. SCHORER, J. \& M. ELFERINK-GEMSER, 2013. How good are we at predicting athletes' futures. Developing sport expertise: researchers and coaches put theory into practice. 2nd ed. London: Routledge, , pp. 30-40.

52. SCHORER, J., N. WATTIE, S. COBLEY \& J. BAKER, 2017. Concluding, but definitely not conclusive, remarks on talent identification and development. Routledge Handbook of Talent Identification and Development in Sport. S.1.: Routledge, pp. 466-476.

53. SIEGHARTSLEITNER, R., C. ZUBER, M. ZIBUNG, B. CHARBONNET \& A. CONZELMANN, 2019. Talent selection in youth football: Technical skills rather than general motor performance predict future player status of football talents. Current Issues in Sport Science (CISS) [en línea], 0(0). [Consulta: 19 junio 2020]. ISSN 2414-6641. DOI 10.15203/CISS_2019.011. Disponible en: https://atemjournal.com/ojs2/index.php/ciss/article/view/2946.

54. SILVA, M. J. C., A. J. FIGUEIREDO, F. SIMÕES, A. SEABRA, A. NATAL, R. VAEYENS, R. PHILIPPAERTS, S. P. CUMMING \& R. M. MALINA, 2010. Discrimination of U-14 Soccer Players by Level and Position. International Journal of Sports Medicine. 31(11), pp. 790-796. ISSN 0172-4622, 1439-3964. DOI 10.1055/s-00301263139.

55. ŠIMONEK, J., 2019. Agility in Sport. S.1.: Cambridge Scholars Publishing. ISBN 1-52754222-X.

56. SÖDERSTRÖM, T., J. FAHLÉN, M. FERRY \& J. YU, 2018. Athletic ability in childhood and adolescence as a predictor of participation in non-elite sports in young adulthood. Sport in Society. 21(11), pp. 1686-1703. ISSN 1743-0437.

DOI 10.1080/17430437.2017.1409726.

57. STEWART, P. F., N. P. CARROLL \& A. N. TURNER, 2019. Strength, Power, Speed, and Agility in Soccer. Elite Soccer Players: Maximizing Performance and Safety, pp. 175.

58. SVENSSON, M. \& B. DRUST, 2005. Testing soccer players. Journal of Sports Sciences. 23(6), pp. 601-618. ISSN 0264-0414. DOI 10.1080/02640410400021294.

59. THE FIFA, 2014. International Federation of Association Football (FIFA). The FIFA Big Count. Retrieved from. International Federation of Association Football (FIFA). [en línea]. 
Disponible en: http://www.fifa.com/worldfootball/bigcount/allplayers.html. Updated February 3rd, 2014.

60. TURNER, A., S. WALKER, M. STEMBRIDGE, P. CONEYWORTH, G. REED, L. BIRDSEY, P. BARTER \& J. MOODY, 2011. A Testing Battery for the Assessment of Fitness in Soccer Players. Strength \& Conditioning Journal. 33(5), pp. 29. ISSN 1524-1602. DOI 10.1519/SSC.0b013e31822fc80a.

61. VESCOVI, J. D., R. RUPF, T. D. BROWN \& M. C. MARQUES, 2011. Physical performance characteristics of high-level female soccer players 12-21 years of age. Scandinavian Journal of Medicine \& Science in Sports. 21(5), pp. 670-678. ISSN 09057188. DOI 10.1111/j.1600-0838.2009.01081.x.

62. WAGNER, H., B. SPERL, J. W. BELL \& S. P. VON DUVILLARD, 2019. Testing specific physical performance in male team handball players and the relationship to general tests in team sports. The Journal of Strength \& Conditioning Research. 33(4), pp. 1056-1064.

63. WALKER, S. \& A. TURNER, 2009. A One-Day Field Test Battery for the Assessment of Aerobic Capacity, Anaerobic Capacity, Speed, and Agility of Soccer Players. Strength \& Conditioning Journal. 31(6), pp. 52. ISSN 1524-1602.

DOI 10.1519/SSC.0b013e3181c22085.

64. WILLIAMS, A. M. \& T. REILLY, 2000. Talent identification and development in soccer. Journal of Sports Sciences. 18(9), pp. 657-667. ISSN 0264-0414. DOI 10.1080/02640410050120041.

65. WORLD MEDICAL ASSOCIATION, 2013. World Medical Association Declaration of Helsinki: ethical principles for medical research involving human subjects. JAMA. 310(20), pp. 2191-2194. ISSN 1538-3598. DOI 10.1001/jama.2013.281053.

66. YILMAZ, G., 2014. The Effects of Power, Speed, Skill and Anaerobic Capacity of Different Training Models in Young Male Basketball Players. The Anthropologist. 18(3), pp. 877-883. ISSN 0972-0073. DOI 10.1080/09720073.2014.11891619.

67. ZEMKOVÁ, E. \& D. HAMAR, 2018. Sport-Specific Assessment of the Effectiveness of Neuromuscular Training in Young Athletes. Frontiers in Physiology [en línea], 9. [Consulta: 23 enero 2020]. ISSN 1664-042X. DOI 10.3389/fphys.2018.00264. Disponible en: https://www.ncbi.nlm.nih.gov/pmc/articles/PMC5904431/. 